\title{
Analysis of Health Sector Budget of Nepal
}

\author{
Ram Krishna Dulal, ${ }^{1}$ Angel Magar, ${ }^{2}$ Shreejana Dulal Karki, ${ }^{3}$ Dipendra Khatiwada, ${ }^{4}$ Pawan Kumar Hamal $^{5}$ \\ ${ }^{1} \mathrm{Nepal}$ Association of Medical Editors, Kathmandu, Nepal, ${ }^{2}$ Health Policy, Planning and Financing, London School of Hygiene \\ and Tropical Medicine, London, United Kingdom, ${ }^{3}$ Lungenklinik Hemer, Theo-Funccius-Str. 1, Hemer, Germany, ${ }^{4}$ Kathmandu \\ Medical College, Sinamangal, Kathmandu, Nepal, ${ }^{5}$ National Academy of Medical Sciences, Tundikhel, Kathmandu, Nepal.
}

\begin{abstract}
INTRODUCTION: Primarily, health sector connects two segments - medicine and public health, where medicine deals with individual patients and public health with the population health. Budget enables both the disciplines to function effectively. The Interim Constitution of Nepal, 2007 has adapted the inspiration of federalism and declared the provision of basic health care services free of cost as a fundamental right, which needs strengthening under foreseen federalism.
\end{abstract}

METHODS: An observational retrospective cohort study, aiming at examining the health sector budget allocation and outcome, was done. Authors gathered health budget figures (2001 to 2013) and facts published from authentic sources. Googling was done for further information. The keywords for search used were: fiscal federalism, health care, public health, health budget, health financing, external development partner, bilateral and multilateral partners and healthcare accessibility. The search was limited to English and Nepali-language report, articles and news published.

RESULTS: Budget required to meet the population's need is still limited in Nepal. The health sector budget could not achieve even gainful results due to mismatch in policy and policy implementation despite of political commitment.

CONCLUSIONS: Since Nepal is transforming towards federalism, an increased complexity under federated system is foreseeable, particularly in the face of changed political scenario and its players. It should have clear goals, financing policy and strict implementation plans for budget execution, task performance and achieving results as per planning. Additionally, collection of revenue, risk pooling and purchasing of services should be better integrated between central government and federated states to horn effectiveness and efficiency.

Keywords: health care; budget; financing; unitary system; federalism.

\section{INTRODUCTION}

The dispute over whether the arrangement of federal states to be apportioned ethnically or territorially in Nepal is not settled yet. However, almost all parties and groups have a consensus on restructuring country as a "Federal Democratic Republic Nepal". ${ }^{1}$ People are getting more and more aware about Nepal's political transition, but only a few ( $17 \%$ of 3,850 respondents) expressed that they heard and knew about restructuring agendas (e.g. federalism). ${ }^{2}$ The establishment of federated health system with a viable financing modality is still unclear, in spite of the series of discussions (2008-2013) hold in the Constitutional Assembly. It has failed to materialize about the number of federated states itself.

The financing aspect plays crucial role to function health systems and increasing attention has been given to the health system financing to address unmet needs and future challenges. The past governments of Nepal implemented health programmes through the

Correspondence: Dr. Ram Krishna Dulal, Nepal Association of Medical Editors, Kathmandu, Nepal. Email: dr.rkdulal@gmail.com, Phone: $+977-9851025545$ 
decentralized health system that could not achieve gainful results as envisioned by the policy. The challenges could be more complex in future under federalism as it will have health policy comprising seeds policies (fragmentation) coming from different federated states. As Nepal is changing from its unitary system to federalism, outlining a federated health system including financial model is imperative. The basic function of collecting revenue, pooling resources, and purchasing goods and services from other federated states as well as guarantee of appropriate resource allocation from central government will be another pertinent issue. It is important not only to bring about measurable improvement in health but it is imperative for the function of federalism. This article shall give some insight on health system performance and quality, fiscal health federalism and also early warning but it does not claim to provide everything how Nepal's health federalism should be designed.

\section{METHODS}

How well a system performs depends on how well it achieves the goals for which it should be held accountable, ${ }^{3}$ where health financing system plays a critical role in overall and achieving broader development goals of health system. ${ }^{4}$ In the context, an observational retrospective cohort study, aiming at analysis of the health sector budget allocation trend and health indicators of Nepal, was carried out. A total of 12 year's budget (Fiscal year 2001/02 to 2012/13) data was gathered and the facts published by the authentic sources including Ministry of Health and Population, Ministry of Finance, Department of Health Services of Nepal and National Planning Commission were assembled. The performance assessment being based on health outcome or effectiveness (including policy implementation) and responsiveness (access to services, equity, public experience, satisfaction) were scanned. Googling was done for the retrieval of further information and reviewed whether the gainful results were achieved as envisioned by health policy. The keywords for search used were: fiscal federalism, health care, public health, health budget, health financing, external development partner, bilateral and multilateral partners and healthcare accessibility.

The keywords were used one at a time and also with several combinations for searching. The search was limited to English-language report, articles and news published. However, health policy 1991, available in Nepali version was used as reference. A few unpublished documents that were distributed during official meeting, conferences and workshops by the Ministry of Health and Population were utilized as reference. The available data were presented in the tables.

\section{RESULTS}

Despite political determination expressed in policy document and progressive legislation, the implementation reported to be slow and unable to meet the expected change. ${ }^{5}$ The Interim Constitution of Nepal 2007 declared the free provision of basic health care services as a fundamental right. ${ }^{6}$ This declaration has given an increased responsibility to the government to meet the needs by increasing the spending in the health sector and the government has committed to boosting spending in the health sector. Further, the Nepal Health Sector Programme (NHSP-2) 2010/2015 calls for the share of health spending in the total government budget to rise from around $7 \%$ in $2010 / 11$ to $9.6 \%$ in $2014 / 15 .^{7}$

Health financing in Nepal primarily relies on out of pocket payment that includes charges or fees levied for consultations, investigations, hospitalization, medicines and other supplies that patients must pay themselves. High out of pocket indicates less efficiency of health care financing. A figure indicated that out of pocket contributed around $60 \%$ (plus and minus) out of total health expenditure. ${ }^{8}$ Still, health sector has made some progress using inspirational goal and targets under decentralized system which is satisfactory to a certain extent.

The Financial Management Division, Department of Health Services, 2012/13 Report $^{9}$ indicated difficulty in financial reporting procedures and reimbursement from donors due to the lack of trained manpower and physical facilities, delay in budget disbursement due to programs not being approved on time, non-release of committed donor budget, difficulty in keeping books of accounts and reporting, according to the differing, formats of the different, donors supporting the same program (p.211). Since Nepal's health sector receives singnificant contribution from its external development partners (EDPs), such delay certainly affects in government activities.

There was inadequate budget allocation to districts for transportation of vaccine and other supplies and fuel for cold chain, delay in budget release affected timely payment to mothers at the time of delivery (p.101). During regional and national reviews, 2012/13 (B.S.2068/69) it was reported that planning process was not rational in practice, inadequate budget for llaka level, meeting and supervision, district plan was ignored by the center while programme planning and budgeting (p.219). The points stated above are not all that are reported in the reports of the fiscal year 2012/13.

On the contrary, the budget absorption capacity seems 
sub-optimal under the current decentralized health system. In the fiscal year 2010/2011 it absorbed $76 \%$ budget that got increased to $94 \%$ in $2012 / 2013$, but external development partners (EDPs) expenditure was low in 2010/2012 compared to allocation, which got slightly increased in 2012/2013 (Table. 1).

Table 1. Budget absorption capacity.

\begin{tabular}{|lllllll|}
\hline & Government & & EDPs & \multicolumn{3}{l|}{ Total } \\
FY & Budget & Expenditure & Budget & Expenditure & Budget & $\%$ Expenditure of Budget \\
$2009 / 2010$ & 9.31 & 9.23 & 8.53 & 6.68 & 17.84 & $89 \%$ \\
$2010 / 2011$ & 13.93 & 11.9 & 9.88 & 6.27 & 23.81 & $76 \%$ \\
$2011 / 2012$ & 15.21 & 13.82 & 9.72 & 6.42 & 24.24 & $81 \%$ \\
$2012 / 2013$ & 11,72 & 11.89 & 8.52 & 7.14 & 19.03 & $94 \%$ \\
\hline
\end{tabular}

Among the challenges, drug availability in health facilities and policy was reported to be mismatched e.g. 7 out of 35 drugs was unavailable; $17 \%$ of all clients found to be paying for drugs because the medicines they required were not on the essential free drugs list. ${ }^{11}$, 12

\begin{tabular}{|c|c|c|c|}
\hline Particulars & $\begin{array}{l}\text { Public } \\
\text { sector } \\
\text { Sanctioned }\end{array}$ & $\begin{array}{l}\text { Private- } \\
\text { for-profit } \\
\text { Sector }\end{array}$ & Total \\
\hline $\begin{array}{l}\text { Doctors, } \\
\text { (including } 335 \\
\text { Scholarship) }\end{array}$ & 1447 & 6888 & 8335 \\
\hline Nurses & 6553 & $\mathrm{n} / \mathrm{a}$ & 6553 \\
\hline Paramedics & 7559 & $\mathrm{n} / \mathrm{a}$ & 7559 \\
\hline $\begin{array}{l}\text { Public health } \\
\text { workers }\end{array}$ & 4289 & $\mathrm{n} / \mathrm{a}$ & 4289 \\
\hline $\begin{array}{l}\text { Alternative } \\
\text { medicine } \\
\text { (Ayurvedic) }\end{array}$ & 785 & $\mathrm{n} / \mathrm{a}$ & 785 \\
\hline $\begin{array}{l}\text { Admn \& } \\
\text { Support }\end{array}$ & 7137 & $\mathrm{n} / \mathrm{a}$ & 7137 \\
\hline Total & 27770 & 6888 & 34658 \\
\hline
\end{tabular}

In oder to improve the health system, 'Health Facility Management Committee' at local level were formed and health care facilties were handed over to local health management committees. Over the years, the Ministry of Health and Polulation handed over a total of 1,433 local health institutions in 29 districts with operational guidelines for managing health facilities at local levels. Orientation was also given to key officials of local management committees aiming at better management and improved health service delivery. However, it was done in a very ad hoc manner without much preparation. Handing over of health facilities on a piecemeal basis in absence of clear vision, policy, and plan invited a number of management problems and critical challenges in health service delivery at the local level. The arrangement did not change the decision making power structure and accountability mechanisms. Upward accountability remained as usual. Therefore, the health system was not able to hear the voice of the people in a meaningful manner. ${ }^{5}$

Expenditure in health remains low in Nepal and per capita health expenditure at US\$18.09 in 2006 . It is reported that expenditure in health remains low at 5.3 percent of GDP in 2006 . The composition of total health expenditure is 44 percent public expenditure, whereas the remaining 56 percent is from private sources. The share of Government stands at 24 percent (US\$ 4.28) of the total health expenditure and external partners contribute the remaining 21 percent (US\$ 3.75). More than 55 percent (US\$9.00) of the total health expenditure is financed through out of pocket expenditure by households at the time of service. ${ }^{13}$

The shortages of medical professionals in rural health facilities have been reported time and again although a great stride have been made in human resource for health production. Dhakal (2009) indicated that the facilities were having continuous shortage of drugs and commodities and high absenteeism of health workers. ${ }^{15}$ Due to poor retention of human resources, many posts of health facilities were not filled. In an average, $85 \%$ sanctioned posts were filled-in out of which only $70 \%$ were posted in public health facilities. ${ }^{5}$ The ratio of filled to sanctioned positions for Ilam, Sarlahi and Baglung was reported to be $74.1 \%, 90.6 \%$ and $80.8 \%$ respectively. As reported by $\mathrm{D}(\mathrm{P}) \mathrm{HOs}$, among the reasons which make the doctors unattractive are the infrastructure, access to capital city and living conditions in the districts. ${ }^{16}$ 
Dulal et al. Analysis of Health Sector Budget of Nepal

\begin{tabular}{|llllll|}
\hline Table 3: Sanctioned and full-filled health human resources & \multicolumn{5}{l|}{${ }^{14}$} \\
\hline Position & Sanctioned & Filled & Vacant & \% of filled positions & Share \% \\
Medical doctor & 1062 & 816 & 246 & 76.84 & 4.34 \\
Nursing staffs including ANMs & 5935 & 5307 & 628 & 89.42 & 24.25 \\
Paramedics & 10,642 & 9212 & 1430 & 86.56 & 43.48 \\
Other & 6838 & 6394 & 444 & 93.51 & 27.94 \\
Total & 24477 & 21729 & 2748 & 88.77 & 100.00 \\
\hline
\end{tabular}

The Ministry of Health and Population indicates that between 1991 and 2008 the population got increased by $35 \%$ while the number of health human resource increased only by $3.4 \%$. The Ministry of Health itself reported that as the aging population will increase during the NHSP-2 period, it will be difficult to meet the demand unless the existing workforce (for health services) is significantly increased. ${ }^{13}$
There is limited financial management capacity in Accounts Sections of Ministry of Health and Population (MoHP) and Department of Health Services (DoHS) for the budgeting and accounting processes. ${ }^{17}$ The current state of affair does stress for a development of human resource capacity in the areas of financial management, strategic planning and use of technology based solutions.

\begin{tabular}{|c|c|c|c|c|c|c|c|c|c|c|c|c|c|}
\hline \multirow{4}{*}{ 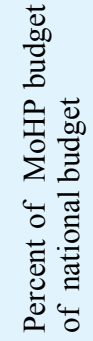 } & $\frac{\text { ㄱ }}{\frac{\delta}{8}}$ & 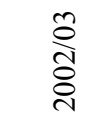 & 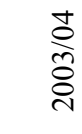 & 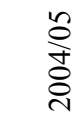 & $\begin{array}{l}\text { ஓ } \\
\text { ஸे } \\
\text { ঠे }\end{array}$ & $\begin{array}{l}\hat{0} \\
\text { o } \\
\text { } \\
\text { ㅇ }\end{array}$ & $\frac{\infty}{\stackrel{\infty}{8}} \underset{8}{\stackrel{0}{0}}$ & 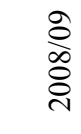 & 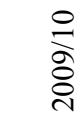 & 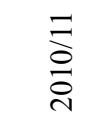 & $\underset{\stackrel{\overbrace{}}{\Xi}}{\stackrel{\sim}{\Xi}}$ & 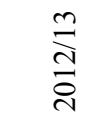 & $\frac{\stackrel{\nabla}{\infty}}{\stackrel{\sim}{2}}$ \\
\hline & $5.2 *$ & $4.9 *$ & $5^{*}$ & $5.3^{*}$ & $6^{*}$ & $6.3^{*}$ & $6.8^{*}$ & 6.33 & 6.24 & 8 & 7 & 4.99 & 6.51 \\
\hline & & & & & & $6.41 \bullet$ & $7.2 \bullet$ & $6.3 \bullet$ & $6.2 \bullet$ & 7.0 & & & \\
\hline & & & & & & & & & & $7.05 \Delta$ & $6.48 \Delta$ & $5.72 \Delta$ & $6.69 \Delta$ \\
\hline
\end{tabular}

Source

* Healthcare Financing in Nepal, Ministry of Health and Population

Government of Nepal and RTI International, May 2010, https://www.rti.org/pubs/41_nepal_healthcarefinancing.pdf. pg.9 w Budget Analysis FY 2009010, Kathmandu, Nepal, p.11

Annual Report, DoHS (2009/2010, 2010/2011, 2011/2012).

$\Delta$ Kedar Bahadur Adhikary, Progress on Public Financial Management, HRFMD MoHP. http://www.nhssp.org.np

In 2001, the population of Nepal was 23.15 million which got increased to 26.5 million in 2011.18, 21 During the same points of time health budget was $5.2 \%$ and $7 \%$ respectively which however was decreased to $4.99 \%$ in 2012/13 (Table: 4). The budget allocation stated in various document vary as indicated above. However, it is certainly debatable whether the reduction in health sector budget was rational when trend of population growth and disease burden are not decreased. The heterogeneity nature of the report on health budget allocation makes hard to comment.

\section{DISCUSSION}

The mismatch in budget allocation and expenditures as well as the health outcome under the current decentralized health system indicates that there is still room for improvements. As the country is moving towards federalism, the core question is what more health benefit will the Nepalese be achieving under envisioned federalism compared to present decentralization. How significant change can be brought particularly in life expectancy, infant mortality, maternal mortality, low birth weights, stunted children due to poverty, teen pregnancy/birth, safe drinking water and safe disposal of excreta, etc.

After the restoration of democracy in 1990s, significant strides in budgetary process have been made and enhanced public accountability of the resource usage is placed in order. ${ }^{19}$ Despite having an enhanced public accountability, budget execution and performance budgeting has been a key weakness; with the delays in implementation of capital projects and slow pace of capital expenditure. Although, the trends of performance of capital expenditure are improved, there are problems and gaps in the budgets provided for the 
projects that are not ready to take off. ${ }^{20}$

In spite of gaps in budget allocation and utilization (Table: 1) ${ }^{10}$ life expectancy of Nepalese at birth has increased from 54, 58 and 64 years in 1990/91, 2000/2001 and $2007 / 08$ respectively. ${ }^{21}$ In 2012, life expectancy at birth continued to increase and it increased to 68 years (M 67/F 69 years). ${ }^{22}$ A significant improvement in equality of access to health servivces during the NHSP I (2004-10) was reported and it exceeded nearly all of the outcome and service output targets that were set for same period. ${ }^{13}$

Maternal deaths have dropped by almost half from 539 per 100,000 live births in 1996 to 281 in 2006 . Infant mortality and under-5 mortality declined to 46 and 54 in 2011 from 79 and 118 in 1996 respectively. The child mortality rate also decreased from 43 in 1996 to 9 in 2011. The neonatal mortality rate (NMR) has come down from 50 per 1000 live births in 199615 to 33 in 2006. The total fertility rate (TFR) declined from 4.6 in 1996 to 2.6 in $2011 .{ }^{23}$

Nepal's health indicator got improved not only due to injecting money ( $\%$ of GDP invested) in to health sector, but a number of factors leaving impact on health e.g. improved nutrition. Foreign remittance earned by family member has helped to buy food, education and health service back home that has contributed to improve health. Unquestionably, any increased budget allocation enables to invest in direct and indirect activities that can have immediate and long-term impact on health outcome.

Considering the current issue of quality and coverage as well as foreseeable health federalism, the authors wish to argue "how long will it take Nepal to increase its citizen's life expectancy to 80 years as an average age Japanese in Asia or Swiss or German nationals in Europe?

Primarily, health sector connects two different segments of health discipline $3 / 4$ medicine and public health, where medicine deals with individuals and public health with the population. ${ }^{24}$. The medical care focus is on treatment and rehabilitation of individuals while public health is on prevention of disease or ill health and promotion of health of the community. ${ }^{25}$ The health sector budget enables both the segments to function successfully and deliver the essential service to unreached population. The available resources for health sector must be allocated in such a way that should produce improved health service and meets competing objectives. Allocation of limited resources to everywhere and wining everything cannot be possible. Similarly, an increased investment must produce improved health service/benefit to the population. Despite the political determination expressed in policy, the part of implementation reported to be slow and did not bring expected changes. ${ }^{5}$

Considering whether not-for-profit and private partnership sector could other options to improve health care, both the sector were welcomed by the national health policy 1991 in Nepal. Today, compared with public sector, a remarkable number of health human resources, mostly the doctors, are being engaged in the private sector (Table 2). The disparity of human resource for health in ratio in urban $3 / 4$ rural and private $3 / 4$ public is big., The private health institutions are profit driven and they are mostly urban-based focusing on selling their medical services. They are hardly given responsibilities of population health activities except some packages of immunization services and reproductive health care. Supply induced demands of medical service, which, of course, is profit driven should be tightly and appropriately regulated. The costs of service of identical nature provided by different private medical institutions are dissimilar. The presence of private health care instutions is more compared to non-governmental organizations (NGOs) including the trust, cooperative and missionary.

HSS and NHSPIP-I stressed to increase the coverage and raise the quality of essential health care services with a special focus for poor and vulnerable group. Devolution of entire health system through decentralization to local bodies and de-concentration of ministry of health's management did not achieve expected outcome.. The overall indicators were still low in compared with the South Asian despite the political commitment and progressive legislation under decentralization of Nepal's health sector. ${ }^{26.27}$

Healthy population can lead to higher gross domestic product (GDP) per capita as well as gross national product in the long run. Improved health care outcomes has in recent years been increasingly recognized as an important factor in the human capital accumulation process--alongside educational attainment--having potentially important spill-over effects on economic growth and welfare. ${ }^{28}$

To win heart of the people, the policy makers may compose very appealing words in policy but it is necessary to put also adequate actions in implementation policy. This is what the authors fear about the future health system under dreamed federalism. It's pretty weird to be reading that no clear picture of federated states and official document on health federalism with fiscal policy has surfaced. Considering about the time spent (2008 to 2013) on discussion on federalism, it seems that the terminology "federalism" is being perceived by majority of Nepalese politicians as a best tool to solve all the obstacles, which is untrue. The fundamental issue is 
how detailed and clear a federated system (policy) is designed and how tighter the implementation policy is formulated to translate the political vision in to reality. Without a meaningful fundamental preparation, it will be truly unrealistic even to imagine having improved population health outcome under federalism.

\section{FEDERALISM STRUCTURE AND POWER SHARING}

Federalism divides sovereignty between a centralized state and regional or local states and the authority might be equal or hierarchical, shared or separate which could deliver improved health services if it is managed properly. On the contrary, federalism could also give very bitter experience like in Yugoslavia and Czechoslovakia where both the countries got splited. ${ }^{29}$ American federalism experimented different republics, confederations, and unions which remains the most striking and enduring example of federalism. Its system has changed radically as the relationship between state and national authority seeks to gain or regain balance. 30 This indicates that the bargaining for power or resources with central government and neighbouring federated states remains continue and even freedom for splitting from a federal states remains unlocked. For instance, neighbouring counrty India created 3 states in 2000: Chhattisgarh from Madhyapradesh, Uttarakhand from Uttar Pradesh and Jharkhand from Bihar and going to recognize a new state of Telangana in soon in $2014 .^{31}$

Michael Burgess in his "Comparative Federalism Theory and Practice" argues "while such a thing as federal theory does exist, there is, as yet, no fully fledged theory of federalism". ${ }^{32}$ It is a form of government that emphasizes both vertical power-sharing across different levels of governance and, at the same time, the integration of different territorial and socio-economic units, cultural and ethnic groups in one single polity. Though there is no established theory of federalism on how to structure federal states, modalities with great philosophy on how to address the social injustice, inequality and discrimination are in place.

The basic principle is driven by self-rule or sharedrule, self-sufficient and shared-resources. Compared to decentralization federalism indicates high autonomy in policy making and implementation. High autonomy means more flexibility and flexibility leads to ambiguity, where politician and policy makers have to be extremely cautious while designing such a system that can have direct and long-term impact on population health. At the same time, it could establish conflicting policy with other federal states within the country and central government. Due to high autonomy principle in federalism, a federal state could develop its own system for education, health, employment, public transport, forest, water, land etc except some areas e.g. national security (army) policy, foreign policy and currencypolicy etc. ${ }^{1}$ The security policy regarding the police is controlled by the federal state or province but army policy is controlled by the central government.

Unlike in decentralization, you will always have a chance to create a new federal state in full democratic system (India, USA). Many countries in the world have adapted federalism; however, they are in a persistent struggle to meet the health service demands in a massive change of national and global economy. American federalism has implications for public health practice: it molds financing and disbursement options, including funding formulas, which affect allocations and program goals, and shapes how funding decisions are operationalized in a political context. ${ }^{33}$

In advance country like United States of America, the annual budget is the final step through which the mission, vision, and plan are translated into reality. The budget establishes goals for all of the balanced scorecard dimensions. Its use makes the budget exercise a way to simultaneously improve quality, efficiency, patient satisfaction, market share, worker satisfaction, and financial position. ${ }^{34}$

In Nepal, its limited capacity for reform and donors' push with certain strings sometimes to implement advance reform without considering the impact of spending and the domestic need may create problems. Similarly, overstretching the national capacity donor driven reform agenda in the priority resulted to less success. ${ }^{19}$

In 2001, about US\$ 3.059 trillion - apparently 9 percent of global gross domestic product (GDP) was spent on healthcare worldwide; however, only 12 percent of this amount was spent in low-middle income countries, which accounts for 84 percent of global population and 92 percent of global disease burden. Nepal belongs to low-middle income countries that allocated nearly half of the gross domestic product (GDP) to health sector in 2001/02 fiscal year than the global gross domestic product (9\% vs. $5.2 \%$ ). ${ }^{35}$ The GDP of low-middle income countries including Nepal itself is very small compared to industrialized countries and Nepal could invests for health sector is a smaller proportion.

The available resources are never sufficient to allow to all available interventions to be provided, and so choices have to be made, which sometimes involve very difficult decisions. ${ }^{36}$ Scarcity of resources, alternative methods and uses. Thus, the Swiss health system is among the best in the OECD. But this excellence comes at a price, with Switzerland spending $11.4 \%$ of GDP on health in 2009 , well above the OECD average of $9.5 \%$ of GDP. ${ }^{37}$ In Nepal, one of the members of official advisory team of the Ministry of Health and Population shared with 
the authors that dialogues to increase the health sector budget to $10 \%$ has taken place, but it still remaining as a suggestion only.

Once the federalism will be implemented, it limits the size and scope of the national government. Then, how the EDPs will be partnering with federations should have a clear policy and guidelines. Depending on the agenda and interests one external partner may be unwelcomed by a federation, the might be invited by other.

If you are to improve population health, utilize the existing public health knowledge and technology. No shortage of knowledge and technology, but shotages are in the areas determination, dedication and honesty. In Nepal, the policy makers and implementing agencies are beating the bushes in recent days. There are pitfalls in policy and practices but the different government formed by different political partries transfer blame to each others for doing inadequate.

\section{SOCIETAL CHALLENGES AND HEALTH BUDGET CEILING}

Philosophically, the health-care services should be paid for according to the ability to pay rather than according to the actual use of the health-care system finds its roots in the egalitarian concept of social justice and is generally adopted in Switzerland, as it is in most of the OECD countries (Australia, Austria, Belgium, Canada, Chile, the Czech Republic, Denmark, Estonia, Finland, France, Germany, Greece, Hungary, Iceland, Ireland, Israel, Italy, Japan, Korea, Luxembourg, Mexico, the Netherlands, New Zealand, Norway, Poland, Portugal, the Slovak Republic, Slovenia, Spain, Sweden, Switzerland, Turkey, the United Kingdom and the United States). ${ }^{38-40}$

WHO stated that the resources devoted to health systems are very unequally distributed, and not at all in proportion to the distribution of health problems. Low and middle income countries account for only $18 \%$ of world income and $11 \%$ of global health spending $(\$ 250$ billion or $4 \%$ of GDP in those countries). Yet $84 \%$ of the world's population lives in these countries, and they bear $93 \%$ of the world's disease burden. These countries face many difficult challenges in meeting the health needs of their populations, mobilizing sufficient financing in an equitable and affordable manner, and securing value for scarce resources. ${ }^{41}$

Nepal, one of the least develop nations in the world with 717 US\$ per capita income ${ }^{42}$ has a weak economic power. The government's spending on public health represents a large share, which itself a part of a small economy. Healthy population is the foundation step for nation building, where a numerous challenges have been there in the past. They are not absent at present and may not be absent in the future. The health science academicians, professionals and policy makers are constantly contemplating about the vastness of health system financing and putting their efforts to find a way out to meet demands.

Statistics and experience from democratic countries indicate that it is possible to reach a level of health care that is politically acceptable to citizens for $8-12 \%$ of GDP, given fair agreement on cost effectiveness. However, Werner Christie, the former Minister of Health of Norway stated that there should be no ceiling on what percentage of GDP countries spend on health as it should reflects the medical need and economic performance. The progress of medical science and ageing population may increase both the relative benefit and cost of health care, requiring greater expenditure. ${ }^{43}$

Prof. Nick Bosanquet argues that effective programme can be low cost. Money spent on health should reflect the medical needs not economic performance. From 1990 to 2005, the OECD countries health spending rose almost twice reaching the limit of taxable capacity. Thus, health spending increment shall align with the same rate as GDP growth of a country and get more value from the money spent on health. ${ }^{44}$ However, the $5 \%$ GDP appeared in the World Health Organization (WHO) documents in 1980s as indicator to invest on health ${ }^{45}$ which should be distinguish based on the individual country's public health needs that may vary year to year, decade to decade.

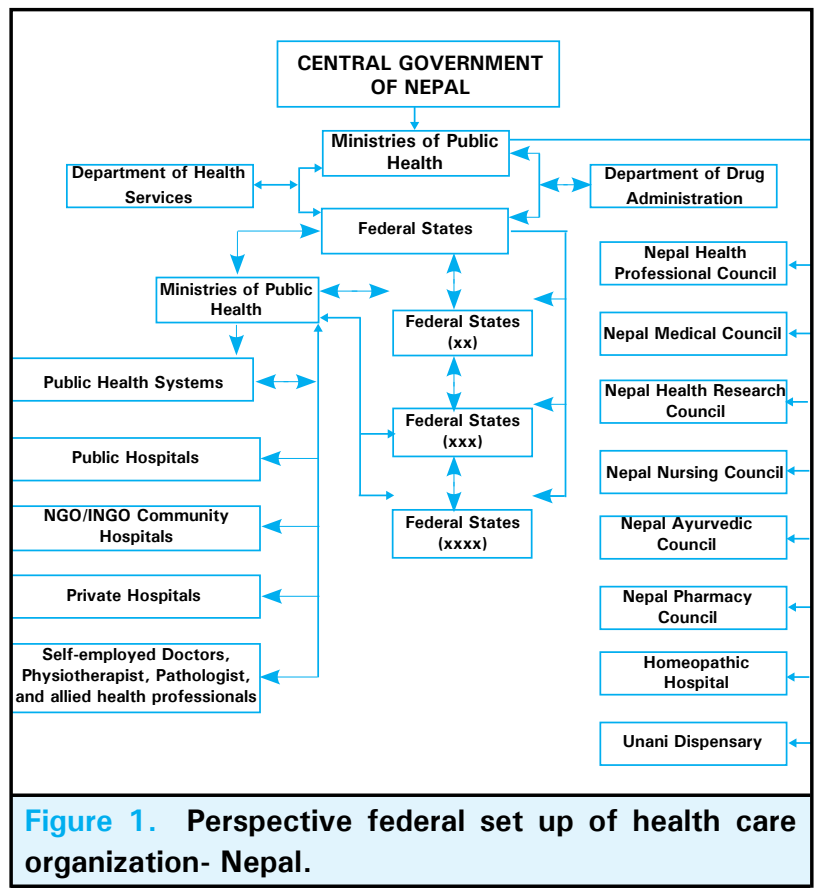

Notably, Nepal's limited economic strength primarily due to the affect of years long civil war between Maoist and the government, the government and the 
developmental work was crippled. Even during that period health budget was well above $(5 \%)$ the indicator that World Health Organization mentioned in 1980s $(5 \%) .46$

In Nepal, free market economy began after 1990s and for-profit providers have entered and increased particularly in medical care. A macro perspective of health federalism with defined goal of improving health service delivery is vital (Figure 1) as the federal states and their resources, and the units within the health care organization will be unexpectedly different and complicated over the first few months and even years of their introduction. ${ }^{46}$

Hospitals are often the provider of last resort for the critically ill and poor that comprise the largest expenditure category of the health systems. As a result, hospitals are often the target of health sector reforms aimed at efficiency, equity, and quality improvements and more systemic reforms in financing and the health care delivery system. ${ }^{47}$ Health systems are not limited to the set of institutions that finance or provide services, but include a diverse group of organizations that produce inputs to those services, particularly human resources, physical resources such as facilities and equipment, and knowledge. ${ }^{48}$

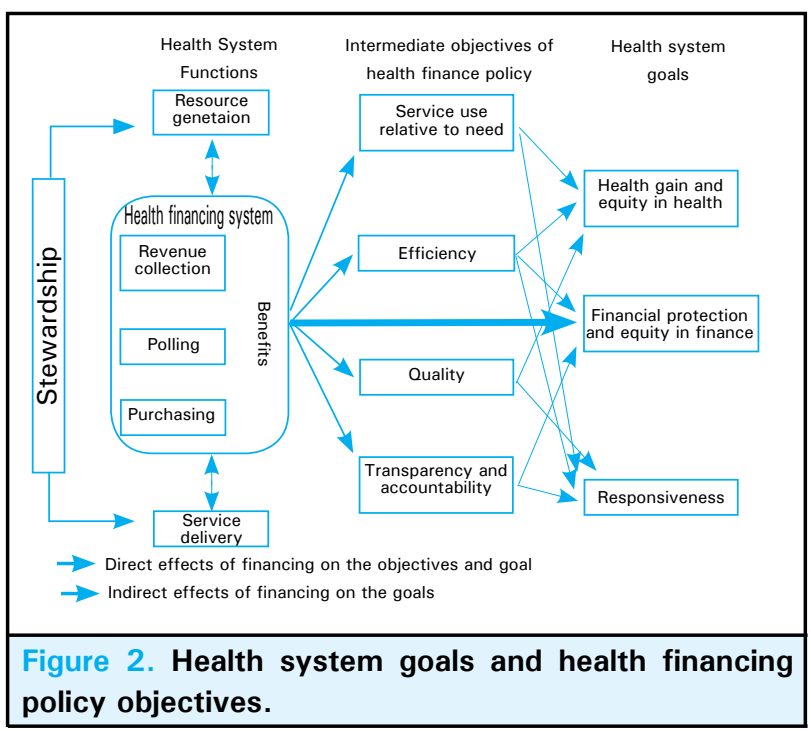

The connection between health financing and overall system goals, directly and indirectly via the intermediate objectives, is depicted by Kutzin (2013) could be a road map for the federal health system. Improvement in equity and universal health coverage backed by financial protection for populations should be the goal. Health financing policy is an integral part of efforts to move towards universal health coverage, but for health financing policy to be aligned with the pursuit of universal health coverage, health system reforms need to be aimed explicitly at improving coverage and the intermediate objectives linked to it, namely, efficiency, equity in health resource distribution and transparency and accountability. ${ }^{49}$

\section{PROGRESS ON FEDERALISM ISSUE}

The Technical Committee of the Constituent Assembly (2008-2012), responsible for organizational restructuring for the new constitution, outlined eight principles for identifying functions and activities of different levels in a federated health structure. It mentioned that all functions and activities identified should also be consistent with the public administration system and public expenditure management protocals". ${ }^{51}$ It can be seen as a too vague statement.

Under federalism, organizational change will take place creating federal ministry of health and population in each federated state, many new levels of administrative structure including staffs, their positions, office set up, logistics, machines and equipment will have to be managed. Nepal needs to work-out adequately about fiscal federalism as it will cause disruption once it changes from its present decentralized structure to federalism. Managing changes in health care organization during the transitional period and after restructuring the unitary Nepal into federal states should be carefully planned. It will prevent unwanted conflict scenario in health care.

\section{CONCLUSION}

There are no mistakes, only lessons if we want to learn from own past and also other health systems. Strengthening any health systems requires to addressing key components including organogram, staff, funds, information, supplies, transport, communications and overall guidance and direction to function. The actions of the health system should be responsive and financially fair, while treating people respectably. ${ }^{52}$ The major focus of Nepal's health sector should no longer be solely on the availability of services and its quality, but also on how the services are delivered to the people where needed and improve health indicators. Policy implementation failure caused by failure in organizing the resources (e.g. right type of structure, manpower, money, machines, methodology) and also the sloppiness in policy implementation process were reported.

Almost all political parties seem to agree that the health systems are underfunded. Just calling for more money is unlikely to be sufficient to improve outcome. The "purpose of health financing is to make funding available, as well as to set the right financial incentives to providers, to ensure that all individuals have access to effective public health and personal health care". This means reducing or eliminating the possibility that an individual will be unable to pay for care, or will be 
impoverished as a result of trying to do so. ${ }^{41}$.

For equalization under federalism, how health budget will be generated and pooled for federated state and how the conditional grant money, loan and foreign aid will be given to the poorer and or local government to finance their programme should be outlined to translate the political vision in to the reality. Although exact number of federal states to be created is unknown, it is clear all federated states have to assume certain relationships between the community, the region, and the nation. Managing changes in health care organization during the transitional period and after restructuring the unitary Nepal into federal states should be carefully planned. ${ }^{46 .}$

\section{WAY FORWARD}

It's it necessary to plan rationally what more will the Nepalese be achieving through federalism compared to decentralization. After defining the all the functions of federated state's Ministry of Health and population and its entities under it linking up to the community level, a health system financing modality should be well-defined. Then, as health system becomes more complex in terms of organizational structure upon adapting federalism, the budget and financial management issues could become even more complex in the near future. Thus, "financing systems need to be specifically designed to: provide all people with access to needed health services (including prevention, promotion, treatment and rehabilitation) of sufficient quality to be effective; [and to] ensure that the use of these services does not expose the user to financial hardship." 47

During the process of change in administrative structure from unitary system to federalism, an interim change provision might of helpful. There is urgency to create well-regulated system with truly tougher implementation process guidelines. Further, an independent evaluation of the policy and structure is imperative to review whether the envisioned policy is practical in Nepal's geo-political and economic context.

1. Sketch a doable progressive vision for the future health federalism including fiscal federalism. Otherwise, it could be like running in to a gray tunnel in a hurry and may end up with an accident.

2. A comprehensible networking plan with / among the neighboring federated states and also central ministry of health and population in a normal and non-normal situations to tackle epidemic, and disasters including clear guidelines how service responsibilities will be shared and financial liabilities will be settled.

3. Healthcare is more a social service than a true industry. But this sector should be run link a notfor profit making industry guided by clear policy and tougher implementation.

4. Envisioned federated health system should ensure equity and produce optimum health across the province / federated state.

5. Identical nature health service (medical) should cost the identical price. Extra cost for luxury (nonmedical) may be charged based on client's / patient's demand and preference. Concept of competition be allowed for same quality.

6. A clear delineation of vertical programme (e.g. immunization) be in place.

7. Functional policy how a federated state should work with partner organization and interlink with national planning commission on health system and health care issues.

8. A continuous monitoring and evaluation of financial performance system should be in place.

9. May train necessary human resource and adapt system improvement tools.

10. Failure to implementation of achievable any work / assignments should be none negotiable

11. A tighter regulation must be in place even to function a competency based system (within federated states).

12. May keep the door open for a predictive, preventive and personalized medicine.

\section{REFERENCES}

1. Khanal KP. Democracy and Federalization of the Nepali State Challenges and Opportunities. Sangam Journal. 2009;1(1):11. Available from: http://www.ccd.org.np/ resources/Krishna $\% 20$ Khanal $\% 20$ Democracy $\% 20$ and $\% 20$ Federalization \%20Article\%20for\%20Sangam\%20Journal_ ENG.pdf.

2. Citizen Survey 2013: Nepal in Transition Nepal Democracy Survey Round III June 2013. Joint survey by State of Democracy in South Asia/Nepal chapter / and International IDEA. Available from: http://www.idea.int/asia_pacific/
nepal/upload/Citizen-Survey-Report-2013.pdf.

3. Murray C JL and Frenk J, A WHO Framework for Health System Performance Assessment, Evidence and Information for Policy, World Health Organization. P.10. http://www. who.int/health-systems-performance).

4. Hort K Goss J Hopkins S and Annear P. Conceptual frameworks, health financing data and assessing performance: A stock-take of tools for health financing analysis in the Asia-Pacific region. Health Policy and Health 
Finance Knowledge Hub (Working Paper Series no. 5). The Nossal Institute for Global. April 2010.

5. Dhakal RP. Analysis of Implementation Challenges of health Sector Decentralization Policy of Nepal, (PhD Thesis), College of Public Health, Chulalongkorn University. 2009, Pg.8.

6. The Interim Constitution of Nepal, 2063 (2007) as amended by the first to sixth amendments. UNDP:Nepal; 2009 Jan. Part3, section 16, sub-section 2, p. 56-70. Distributed by Centre for Constitutional Dialogue (CCD), Alfa Beta Complex, Buddhanagar, Kathmandu, Nepal.

7. Budget Analysis 2011/ 12. Ministry of Health and Population Ramshahpath, Kathmandu, Nepal, 2012. Available from: http://www.nhssp.org.np/health_ financing/Budget\%20Analysis\%202011-12.pdf.

8. Shiva Raj Adhikari. An Evaluation of Nepal's Free Health Care Schemes: Evidence from a Quasi-Experimental Design. (Working paper). July, 2013. Available from: http:// papers. ssrn.com/sol3 $/$ papers.cfm?abstract_id=2289344 .

9. Annual Report, Department of Health Services, 2067/68 (2010/2011), Government of Nepal, Ministry of Health and Population, Kathmandui, Nepal; 2011.

10. Ministry of Health and Population (MoHP). Progress Report on Financial Management. In Nepal's Health Sector 2012/13 Report Prepared for Joint Annual Review (JAR). January 2014, Government of Nepal (GoN), Ramshah Path, Kathmandu, Nepal (http://www.nhssp.org.np/jar/2014/03\%20\%20 Financial\%20Mgt\%20\%20JAR\%20Report\%20Final.pdf).

11. Bhusal CL et al. Report of Status of Free Health Care Services at Health Posts and Sub- Health Posts in Nepal. Nepal Health Research Council, Kathmandu, Nepal; 2010.

12. Suvedi BK et al. Service Tracking Survey, 2011. Ministry of Health and Population, Kathmandu, Nepal; 2012.

13. Nepal Health Sector Programme-II (NHSP-2) 2010 - 2015. Government of Nepal, Ministry of Health and Population. 1 June 2010. P.93.

14. Ministry of Health and Population. Human Resources for Health Strategic Plan 2011-2015 (Draft). January 2012, p.37.

15. Dhakal RP. Addressing the challenges to health sector decentralization in Nepal: an inquiry into the policy and implementation processes. Available from: http://www. nmcth.edu/images/gallery/Editorial/YhxaUr_dhakal.pdf.

16. Bhusal CL et al. District Health Assessment: To Guide the Design of the National Health Insurance Scheme, Kathmandu, Nepal. 2013 June. p. 50.

17. Ensor T, Tiwari S, Assad AR. Health Financing \& Financial Management Capacity Assessment for Health Systems Strengthening. 2000. p.15.

18. Central Bureau of Statistics, National Planning Commission Secretariat, Government of Nepal, Kathmandu, Nepal, November, 2012. National Population and Housing Census 2011, National Report. Volume 01, NPHC 2011.

19. Bhanu Prasad Acharya, How do budget reforms link to development outcomes? A Nepalese Experience. The Nepalese Journal of Public Financial Management (PEFA)
Journal Year - II Issue - 3, Dec 2013. P.1

20. Udaya Pant, Realistic Budgeting for capital Expenditure: Suggested Draft Mechanism of Segregation of Budget into Approved Budget Projects and Projects Carried Forward/ or in Pipeline, The Nepalese Journal of Public Financial Management (PEFA).2013;2(3):73.

21. RTI International. Health System Performance. Research Triangle Park, NC, USA. 2010.

22. WHO. Stastics. Availabe from: http://www.who.int/ countries/npl/en/.

23. Ban B, Tuladhar S, Pant S, and Suvedi BK. Review of Health and Health Service Improvements in Nepal. J Nepal Health Res Counc. 2012 May;10(21):76-81.

24. Distinctions Between Public Health \& Medicine. Availabe from: http://www.hsph.harvard.edu/about/public-healthmedicine/.

25. Jha N. Revitalizing Primary Health Care and activities in Nepal. Health Renaissance 2013;11(3):185-191.

26. Ministry of Health, Nepal Health Sector program implementation plan, NHSP-IP, Kathmandu, MInistry of Health, Kathmandu; 27.

27. World Bank. The Millenium Development Goal for the Health: Rising to the challenges, Washington DC, World Bank. 2004.

28. Price R, Erlandsen E, and Joumard E. Spending Efficiency in Health Care and Economic Growth. Availabe from: http:// hdl.handle.net/11094/22973 . p.57).

29. Brian Galligan. Federalism, Subnational Government and Rights Protection. [online]. 2007 Sep 24-26 [cited 2009 Apr 3]. Available from: http://arts.monash.edu.au/psi/ news-and-events/apsa/refereed-papers/au-nz-politics/ galligan.doc

30. Federalism, Political Theories for Students. Availabe from: http:// www.encyclopedia.com/article-1G2-3424700014/ federalism.html. This indicates, creation of federations is not the ending of problem forever.

31. States and union territories of India. Availabe from: http:// en.m.wikipedia.org/wiki/States_and_union_territories_of_ India.

32. Michael Burgess. Comparative Federalism Theory and practice. First published 2006 by Routledge. Park Square, Milton Park, Abingdon, Oxon OX14 4RN, UK; p.1.

33. Ogden LL. How Federalism Shapes Public Health Financing, Policy, and Program Options. J Public Health Management Practice. 2012;18(4):317-322.

34. Griffith JR and RW Kenneth. The Well-Managed Health Organization, Sixth Edition, Health Administration Press, Chicago: Illinois AUPHA Press, Washington, DC, AUPHA, HAP;2007. p.75.

35. George Schieber, Cristian Baeza, Daniel Kress, and Margaret Maier. Financing Health Systems in the 21st Century. Availabe from: http://www.ncbi.nlm.nih.gov/books/ NBK11772/pdf/ch12.pdf.

36. Gray AM, Clarke PM, wolstenholme JL, wordsworth S, 
Applied Cost-Effectiveness Analysis in Healthcare, 2011: Oxford university press, New York. 2011.p.1

37. OECD/WHO (2011), OECD Reviews of Health Systems: OECD Publishing, Switzerland. 2011. Availabe from: http:// dx.doi.org/10.1787/9789264120914-en. p.157.

38. Crivelli L and Salari P. The inequity of the Swiss health care system financing from a federal state perspective. International Journal for Equity in Health. 2014;13:17. Availabe from: $\quad$ http://www.equityhealthj.com/ content/13/1/17.

39. The inequity of the Swiss health care system financing from a federal state perspective. Availabe from: http://www. equityhealthj.com/content/pdf/1475-9276-13-17.pdf

40. OECD/WHO (2011), OECD Reviews of Health Systems: OECD Publishing, Switzerland; 2011. Availabe from: http:/ / dx.doi.org/10.1787/9789264120914-en. p.157.

41. The world health report 2000 - Health systems: improving performance. Availabe from: http://www.who.int/ whr/2000/en/whr00_en.pdf?ua=1.

42. Central Bureau of Statistics. Estimation: 2012/13): Nepal. 2013.

43. Christie W. Should there be a ceiling on what percentage of GDP countries spend on health? No. BMJ 2008;337:a1036.

44. Bosanquet N. Should there be a ceiling on what percentage of GDP countries spend on health? Yes. BMJ 2008;337:a1040.
45. William D. Savedoff. What Should A Country Spend On Health Care? Health Affairs. 2007;26 (4):962-970.

46. Dulal RK. Health Federalism: The Role of Health Care Professionals in Nepal. JNepal Med Assoc. 2009;48(174):191-5.

47. Preker AS and Harding A (Ed). Innovations in Health Service Delivery: The Corporatization of Public Hospitals. The World Bank, Washington, D.C. 2003 Jan. http:/ / www. who.int/bulletin/volumes/91/8/12-113985/en/ or doi http://www.who.int/bulletin/volumes/91/8/12-113985. pdf.

48. Roemer, MI. National Health Systems of the World, Vol. 1: The countries: Oxford University Press, New York;1991.

49. Kutzin J. Health financing for universal coverage and health system performance: concepts and implications for policy. Availabe from: http://www.who.int/bulletin/ volumes/91/8/12-113985.pdf

50. Tiwari et al. Budget Analysis. January 2012. Ministry of Health and Population, Ramshahpath, Kathmandu, Nepal. 2012.

51. Baker C. Designing Federal Structure in Nepal. Ministry of Health and Population, Ramshahpath, Kathmandu, Nepal. 2012 April.

52. World Helath Organization. Monitoring the Building Blocks of the Health System: A Handbook of Indicators and their Measurement Strategies. 2010. 